\title{
SISTEM DAN PROSEDUR PENGENDALIAN INTERNAL PEMBERIAN KREDIT PADA UED-SP DESA TANAH MERAH, SIAK HULU, KAMPAR
}

\author{
INTERNAL CONTROL SYSTEM AND PROCEDURES OF LENDING \\ ACTIVITIES IN UED-SP DESA TANAH MERAH, SIAK HULU, KAMPAR
}

\author{
Febdwi Suryani \\ Sekolah Tinggi Ilmu Ekonomi Pelita Indonesia \\ febdwi.suryani@gmail.com
}

\begin{abstract}
This study aims to analyze the internal control system and procedures of lending activities in UED-SP Desa Tanah Merah Kecamatan Siak Hulu Kabupaten Kampar. Internal control of lending activities to an organizations is one important aspect. Data resources used in this study are from interview and questionnaires by the UED-SP managers and the datas were analyzed by descriptive method and sign test. The result found that internal control of lending activities of UED - SP Desa Tanah Merah has been running effectively in organizational structure, authorization system and recording procedures, healthy practices and qualified management.
\end{abstract}

Keywords : internal control system and procedures, organizational structure, authorization system and recording procedures, healthy practices, qualified management, sign test.

\begin{abstract}
ABSTRAK
Penelitian ini bertujuan untuk menganalisis pengendalian internal pemberian kredit pada UED SP Desa Tanah Merah Kecamatan Siak Hulu Kabupaten Kampar. Pengendalian internal pemberian kredit pada suatu organisasi yang merupakan salah satu aspek yang penting. Sumber data dalam penelitian ini adalah melalui hasil wawancara dan angket yang di isi oleh pengelola pengelola UED-SP. Data dianalisis menggunakan metode deskriptif dan Uji Tanda (Sign test). Hasil penelitian diperoleh bahwa pengendalian internal pemberian kredit pada UED - SP Desa Tanah Merah Kecamatan Siak Hulu Kabupaten Kampar telah berjalan dengan efektif dari segi struktur organisasi, sistem otorisasi dan prosedur pencatatan, praktik yang sehat, pengelola yang bermutu, uji tanda.
\end{abstract}

Kata Kunci : sistem dan prosedur pengendalian internal, struktur organisasi, sistem otorisasi dan prosedur pencatatan, praktik yang sehat, pengelola yang bermutu, uji tanda.

\section{PENDAHULAN}

Sejak awal kemerdekaan, bangsa Indonesia telah mempunyai Perhatian besar terhadap terciptanya masyarakat yang adil dan Makmur, sebagaimana termuat dalam alinea keempat UndangUndang Dasar 1945. Program - program Pembangunan yang dilaksanakan selama ini juga memberikan perhatian besar terhadap upaya pengentasan kemiskinan karena pada dasarnya pembangunan yang dilakukan bertujuan untuk meningkatkan kesejahteraan masyarakat. Pembangunan merupakan sebagai suatu usaha atau rangkaian usaha pertumbuhan dan perubahan yang berencana yang dilakukan secara sadar oleh suatu bangsa, negara dan pemerintahan menuju modernitas dalam rangka Pembinaan bangsa.

Upaya memberdayakan manusia adalah sangat strategis dan menempati posisi kunci bagi setiap Negara seperti yang disampaikan oleh United Nations 
Children's Fund ( UNICEF 1997 : 2 ) sebagai berikut : akan tiba saatnya ketika bangsa - bangsa dinilai bukan oleh kekuatan militer atau ekonominya, juga bukan oleh kemegahan bangunanbangunan di ibu kota negaranya. Tapi oleh kesejahteraan rakyatnya, oleh tingkat kesehatan, gizi dan pendidikan mereka serta kesempatan memperoleh upah kerja yang layak. Juga oleh kemampuan mereka berpartisipasi dalam berbagai keputusan yang berdampak pada kehidupannya, oleh rasa hormat yang ditujukan kebebasan hak sipil dan politiknya oleh peluang khusus yang disediakan untuk mereka yang rentan dan lemah, serta oleh perlindungan yang diberikan bagi pertumbuhan rohani dan jasmani anak anak.

Semakin meningkatnya kebutuhan masyarakat dan terbatasnya kemampuan dalam memenuhi kebutuhan tersebut, maka masyarakat memerlukan bantuan pemerintah maupun swasta, karena dari sinilah kegiatan ekonomi real dapat berkembang. Pengusaha dalam skala kecil dan menengah sangat memerlukan bantuan keuangan dengan cara kredit untuk mengembangkan usahanya. Oleh karena itu,keberadaan lembaga keuangan yang salah satu kegiatan usahanya adalah pemberian kredit mutlak diperlukan.

Dalam materi (Chapter ke 7) dari Wilkinson, Cerullo, Raval, and Wong-On-Win. Disebutkan bahwa aktifitas pengendalain dapat digolongkan dalam 2 kategori, yaitu : (1) Aktifitas Pengendalian yang berhubungan dengan Laporan Keuangan digolongkan menurut penggunaannya dalam sebuah sistem, antara lain

Preventive control, Detective Control, Corrective Control, dan Security Measures, (2) Aktifitas Pengendalian yang berkenaan dengan pengolahan informasi yang digolongkan menurut aplikasi / penerapannya dalam sebuah sistem, antara lain: General controls, Application controls.

Adapun cara untuk memecahkan masalah dalam penelitian ini, penulis coba mengemukakan dan berpijak pada teori yang ada hubungannya dengan masalah yang diteliti. Sehingga dari teori tersebut diharapkan dapat memberi dasar dan arah penelitian yang dilakukan. Di dalam penelitian ini penulis akan mengemukakan beberapa teori yang penulis anggap relevan dengan permasalahan di dalam penelitian ini. Adapun yang dimaksud dengan UED - SP yaitu lembaga pedesaan yang bergerak di bidang keuangan untuk menunjang usaha ekonomi produktif di desa yang bersangkutan. Sedangkan kredit UEDSP adalah pinjaman yang diberikan oleh UED-SP kepada pihak peminjam untuk membiayai usaha tertentu dengan jumlah tertentu dan jangka waktu tertentu, serta pihak peminjam wajib mengembalikan pinjamannya beserta bunga atau jasa pinjaman.

Berdasarkan Pergub No 20 Tahun 2009 yang disahkan oleh Gubenur Riau , ada lima faktor yang lazim dipakai dalam penilaian analisa kelayakan kredit, yaitu :

1. Character adalah informasi mengenai kepribadian calon nasabah termasuk sifat - sifat pribadi, perilaku perlu diteliti secara hati - hati

2. Capacity adalah upaya menilai calon nasabah untuk mendapatkan kepastian akan kemampuan keuangan dapat dilihat jumlah pendapatan dikurangi dengan jumlah biaya yang terjadi pada calon nasabah

3. Capital adalah upaya untuk mngetahui modal yang dimiliki oleh calon nasabah agar diperoleh kepastian adanya jaminan terhadap 
kredit yang akan diberikan. Modal ini bisa dilihat dari neraca yang dimiliki oleh calon nasabah.

4. Collateral adalah agunan yang diberikan sebagai jaminan kredit, agunan ini sebagai bukti dan keyakinan atas kemampuan dan kemauan nasabah dalam mengembalikan kreditnya. Agunan adalah merupakan penyelamat terakhir bagi keselamatan kredit.

5. Condition adalah menggambarkan kondisi usaha calon nasabah misalnya : peluang pasar, bahan baku, pesaing, aturan pemerintah dll.

Berdasarkan

Pemberdayaan Desa (PPD) Provinsi Riau dalam meningkatkan perekonomian masyarakat dan meningkatkan kesejahteraan hidup masyarakat, maka Pemerintah Daerah Provinsi Riau bekerja sama dengan Pemerintah Daerah Kabupaten setempat memberikan bantuan pinjaman keuangan yang diberikan kepada masyarakat untuk dikelola sebaik mungkin dengan mengacu pada petunjuk teknis yang telah ditentukan. Bantuan tersebut berupa modal pinjaman yang akan diberikan kepada masyarakat melalui Program Pengembangan Lembaga Ekonomi Pedesaan.( PPELP) yaitu usaha ekonomi desa-simpan pinjam (UEDSP). UED-SP Tanah Merah didirikan pada tanggal 19 bulan Juni tahun 2008. Berdasarkan surat Pengesahan didirikan berdasarkan hasil musyawarah mufakat yang mana pengurus-pengurusnya dipilih dari, oleh dan untuk kepentingan masyarakat.

Pelaksanaan Musyawarah Desa Pertanggungjawaban Tahunan (MDPT) UED-SP Tanah Merah mempunyai maksud dan tujuan sebagai berikut :

1. Sebagai bentuk laporan pertanggungjawaban yang dilakukan oleh penggurus atau pelaku PPD terhadap masyarakat/ anggota yang dilakukan selama1( satu) tahun.

2. Sebagai sarana untuk menampung sarana aspirasi dari masyarakat.

3. Sebagai wadah untuk menentukan dan merumuskan langkah-langkah yang akan diambil melalui musyawarah untuk kemajuan UEDSP.

4. Sebagai sarana informasi terhadap perjalanan dan perkembangan UEDSP kedepannya.

UED - SP memiliki aturan seperti yang diatur dalam Surat Mendagri Nomor 412/2420/SJ Tanggal 26 Oktober 1998. Setiap saat UED - SP bisa menerima anggota baru berdasarkan ketentuan yang ditetapkan. Kemudian anggota baru harus membayar simpanan pokok Rp. $50.000,00$.

Sistem kredit adalah aliran uang, berdasarkan kepercayaan, dari orang yang meminjamkan ke orang yang meminjam, dan sebaliknya. Ada pemehaman bahwa uang yang dipinjamkan itu akan dikembalikan dalam rentang waktu tertentu. Supaya sistem tetap berfungsi, peminjam harus melunasi utangnya tepat waktu. Terlalu banyak kegagalan bisa menimbulkan kerusakan fatal pada sistem. Memahami sistem kredit membantu Anda mengelola pinjaman dengan lebih baik.

Pengertian kredit pada pasal 1 angka 11 Undang-Undang nomor 10 tahun 1998 tentang perubahan undangundang Nomor 7 tahun 1992 tentang perbankan adalah penyediaan uang atau tagihan berdasarkan persetujuan atau kesepakatan pinjam meminjam antara bank dengan pihak lain yang mewajibkan pihak peminjam untuk melunasi utangnya setelah jangka waktu tertentu dengan pemberian bunga.

Berdasarkan Pergub No 20 Tahun 2009 yang disahkan oleh Gubenur Riau,ada 3 tahap pemberian 
kredit yang dilakukan dalam pemberian kredit,yaitu :

a.Tahap Permohonan Kredit : Pada tahap ini calon peminjam mengajukan permohonan kredit, pada umumnya melalui pengisian blangko permohonan yang telah disediakan oleh UED-SP.

b. Tahap Penilaian Kredit : Berdasarkan permohonan kredit yang diterima, maka pihak UED-SP melakukan penilaian / evaluasi terhadap kelayakan kredit yang didasrkan atas penilaian kelayakan usaha dari calon penerima kredit. Biasanya dinamakan verifikasi, dan ada 5 tahapan verifikasi yaitu pembahasan awal proposal, kunjungan lapangan, umpan balik, pembahasan akhir, dan rekomendasi. Hasilnya dibawa ke MD II untuk diputuskan layak atau tidak.

c. Tahap Pemutusan dan Realisasi Kredit : Dari penilaian tersebut, maka lembaga pengkreditan mengambil kepuusan dicairkan, di tunda, atau di tolak.

Dari beberapa pengertian kredit di atas dapat di tarik beberapa unsur yang memungkinkan terjadinya kredit. Adapun unsur-unsur kredit (Kasmir, 2004) tersebut adalah

1. Kepercayaan

Kepercayaan yaitu suatu keyakinan bagi kreditur bahwa kredit yang diberikan (baik berupa uang, jasa atau barang) akan benar-benar diterimanya kembali dimasa yang akan datang sesuai jangka waktu kredit.

2. Kesepakatan

Unsur percaya didalam kredit juga mengandung unsur kesepakatan antara kreditur dengan debitur. Kesepakatan ini dituangkan dalam suatu perjanjian dimana masingmasing pihak menandatangani hak dan kewajibannya masing-masing.
3. Jangka waktu

Setiap kredit yang diberikan memiliki jangka waktu tertentu, jangka waktu ini mencakup masa pengembalian kredit yang telah disepakati. Jangka waktu tersebut bisa berbentuk jangka pendek (dibawah 1 tahun), jangka menengah (1 sampai 3 tahun) dan jangka panjang (diatas 3 tahun). Jangka waktu merupakan batas waktu pengembalian angsuran kredit yang sudah disepakati kedua belah pihak.

4. Resiko

Akibat adanya tenggang waktu, maka pengembalian kredit akan memungkinkan suatu resiko tidak tertagihnya atau macet pemberian suatu kredit. Semakin panjang suatu jangka waktu kredit, maka semakin besar resikonya, demikian pula sebaliknya.

5. Balas jasa

Balas jasa bagi bank merupakan keuntungan atau pendapatan atas pemberian suatu kredit. Balas jasa kita kenal dengan nama bunga. Disamping balas jasa dalam bentuk bunga bank juga membebankan kepada nasabah biaya administrasi kredit yang juga merupakan keuntungan bagi bank.

Pemberian kredit mempunyai tujuan tertentu. Tujuan pemberian kredit tersebut tidak akan terlepas dari misi bank. Adapun tujuan utama pemberian kredit menurut (Kasmir, 2004) adalah sebagai berikut:

1. Mencari keuntungan

Tujuan utama pemberian kredit adalah untuk memperoleh keuntungan. Hasil keuntungan ini diperoleh dalam bentuk bunga yang diterima oleh bank sebagai balas jasa dan biaya administrasi kredit yang dibebankan pada nasabah. 
2. Membantu usaha nasabah

Tujuan selanjutnya adalah untuk membantu usaha nasabah yang membutuhkan dana, baik dana untuk investasi maupun dana untuk modal kerja. Dengan dana itu maka pihak debitur dapat mengembangkan dan memperluas usahanya.

3. Membantu pemerintah

Bagi pemerintah semakin banyak kredit yang diberikan oleh pihak bank, maka semakin meningkatkan jumlah kegiatan ekonomi yang akan terjadi. Mengingat semakin banyak kredit berarti adanya peningkatan pembangunan berbagai sektor.

Organisasi bank dalam kehidupan perekonomian yang modern, banyak memegang peranan yang sangat penting sehingga bank selalu diikutsertakan dalam menentukan kebijakan di bidang moneter. Hal ini menyebabkan, bank mempunyai pengaruh yang sangat luas dalam bidang kehidupan khususnya di bidang ekonomi. Fungsi kredit perbankan dalam kehidupan perekonomian dan perdagangan antara lain sebagai berikut

1. Kredit pada hakekatnya dapat meningkatkan daya guna uang.

2. Kredit dapat meningkatkan peredaran dan lalulintas uang.

3. Kredit dapat pula meningkatkan daya guna peredaran barang.

4. Kredit sebagai salah satu alat stabilitas ekonomi.

5. Kredit dapat meningkatkan kegairahan berusaha.

6. Kredit dapat meningkatkan pemerataan pendapatan.

7. Kredit sebagai alat meningkatkan hubungan internasional.

Menurut Rahayu dan Suhayati ( 2010), pengendalian internal adalah suatu proses-yang dijalankan oleh dewan komisaris manajemen, dan personel lainnya dalam suatu entitas yang didesain untuk memberikan keyakinan memadai tentang pencapaian tujuan-tujuan berikut ini: (a) keandalan pelaporan keuangan, (b) menjaga kekayaan dan catatan organisasi, dan kepatuhan terhadap hukum dan peraturan yang berlaku serta efektifitas dan efesiensi operasi.

Pengertian system menurut Widjajanto (2008) adalah"sesuatu yang memiliki bagian-bagian yang soling berintraksi untuk mencapai Tujuan tertentu melalui tiga tahapan yaitu input, proses, dan output". Sistem Pengendalian internal mencakup rencana organisasi dan semua metode serta tindakan yang telah digunakan dalam perusahaan untuk mengamankan aktivitasnya, mengecek kecermatan dan keandalan dari data akuntansinya, memajukan efisiensi operasi, dan mendorong ketaatan pada kebijaksanaan - kebijaksanaan yang telah ditetapkan pimpinan (Mulyadi 2008).

Menurut Reeve dkk (2011), elemen dalam pengendalian internal ada 5 antara lain :

1. Lingkungan pengendalian (control environment), suasana organisasi yang mempengaruhi kesadaran penguasaan (control consciousness) dari seluruh pegawainya. Lingkungan pengendalian ini merupakan dasar dari komponen lain karena menyangkut kedisiplinan dan struktur.

2. Penaksiran resiko (risk assestment), adalah proses mengidentifikasi dan menilai resiko-resiko yang dihadapi dalam mencapai tujuan. Setelah teridentifikasi, manajemen harus menentukan bagaimana mengelola / mengendalikannya.

3. Aktivitas pengendalian (control activities), adalah kebijakan dan prosedur yang harus ditetapkan untuk meyakinkan manajemen 
bahwa semua arahan telah dilaksanakan. Aktivitas pengendalian ini diterapkan pada semua tingkat organisasi dan pengolahan data.

4. Informasi dan Komunikasi (Information and Communication) Informasi dan komunikasi merupakan elemen-elemen yang penting dari pengendalian intern perusahaan. Informasi tentang lingkungan pengendalian, penilaian resiko, prosedur pengendalian dan monitoring diperlukan sebagai pedoman operasional dan menjamin ketaatan dengan pelaporan hukum dan peraturan-peraturan yang berlaku pada perusahaan.

5. Pemantauan (Monitoring), pemantauan terhadap sistem pengendalian internal akan menemukan kekurangan serta meningkatkan efektivitas pengendalian. Pengendalian internal dapat di monitor dengan baik dengan cara penilaian khusus atau sejalan dengan usaha manajemen. Usaha pemantauan dilakukan dengan cara mengamati perilaku karyawan atau tanda-tanda peringatan yang diberikan oleh sistem akuntansi. Penilaian secara khusus biasanya dilakukan secara berkala saat terjadi perubahan pokok dalam strategi manajemen senior, struktur korporasi atau kegiatan usaha.

Pemi Rosalina Hadi (2014) melakukan penelitian mengenai "Sistem Pengendalian Internal Pemberian Kredit Pada Bank Danamon Cabang Kembang Jepun Surabaya". Penelitian ini menggunakan metode analisis kualitatif deskriptif. Hasil penelitian menyatakan bahwa sistem pengendalian internal pada pemberian kredit yang sudah diterapkan pada PT. Bank Danamon Indonesia, Tbk Kantor Cabang
Kembang Jepun Surabaya memenuhi unsur-unsur pengendalian internal.

Nilawati (2016) melakukan penelitian mengenai :Sistem Pengendalian Intern Pemberian Kredit Pada Badan Usaha Milik Desa (Bumdes) Desa Pengastulan, Kecamatan Seririt, Kabupaten Buleleng". Penelitian ini menggunakan metode analisis kualitatif deskriptif. Hasil penelitian menyatakan bahwa sistem pemberian kredit pada BUMDes Artha Werdhi Sarana Desa Pengastulan secara garis besar telah memiliki sistem pengendalian intern yang memadai.

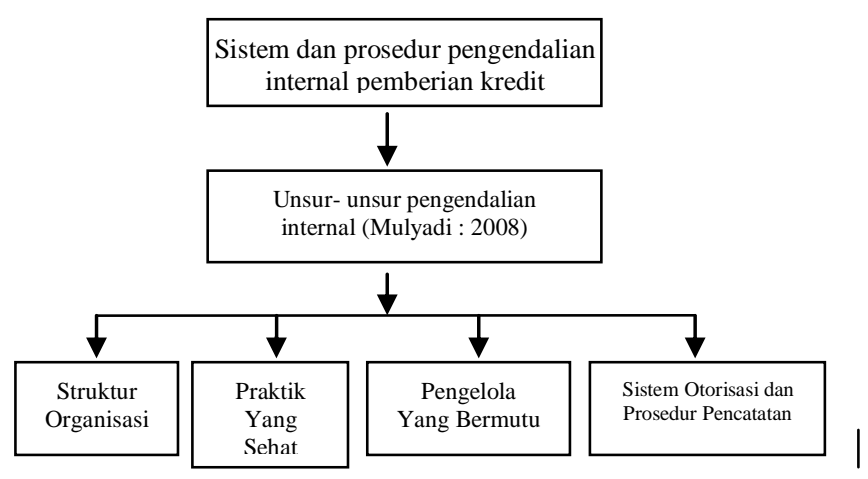

\section{METODE PENELITIAN \\ Tempat Penelitian}

Penelitian ini dilakukan di Desa Tanah Merah, Kecamatan Siak Hulu Kabupaten Kampar.

\section{Variabel dan Instrumen Penelitian}

Populasi dalam penelitian ini adalah seluruh Pegawai Kantor UED SP Desa Tanah Merah Kecamatan Siak Hulu Kabupaten Kampar. Dalam melakukan pengambilan sampel penulis menggunakan teknik sensus untuk pegawai UED - SP Desa Tanah Merah. Sedangkan kepala UED - SP Desa Tanah Merah dijadikan sebagai key informance.

Variabel dalam penelitian ini adalah analisis pengendalian internal pemberian kredit. Pengendalian internal merupakan bagian dari masing-masing sistem yang dipergunakan sebagai prosedur dan pedoman operasional 
perusahaan atau organisasi tertentu. Perusahaan pada umumnya menggunakan sistem pengendalian internal dalam menjalankan kegiatan operasi perusahaan dan mencegah terjadi penyalahgunaan sistem.

\section{Untuk}

menganalisis pengendalian internal pemberian kredit, maka yang dijadikan fokus penelitian berdasarkan teori Mulyadi (2010) adalah pengendalian internal perusahaan yang meliputi unsur-unsur pengendalian internal :

1) Struktur organisasi

Dengan melihat struktur organisasi akan dapat diketahui pembagian tugas dan wewenang, serta bagianbagian yang bertanggungjwab mengenai suatu fungsi dari organisasi perusahaan dan dari struktur organisasi akan dapat diketahui secara rinci deskripsi kerja masing-masing bagian. Struktur organisasi diukur berdasarkan 11 pertanyaan.

2) Sistem Otorisasi dan Pencatatan

Setiap transaksi hanya terjadi atas dasar otorisasi dari pejabat yang berwenang dan pencatatan yang dilakukan harus sesuai dengan prosedur yang ada. dengan meneliti sistem dan prosedur yang ada sudah berjalan dengan baik sehingga dapat mengurangi kecurangan dan penyelewengan yang mungkin terjadi dalam perusahaan. Sementara itu, perubahan dalam pencatatan penghasilan karyawan direkonsiliasi dengan daftar gaji karyawan dan diverifikasi oleh fungsi akuntansi. Sistem Otorisasi dan Pencatatan diukur berdasarkan 15 pertanyaan.

3) Praktik yang Sehat

Pembagian tanggung jawab fungsional dan sistem wewenang serta prosedur pencatatan yang telah ditetapkan dapat berjalan dengan baik apabila didukung dengan praktik yang sehat. Praktik yang sehat diukur berdasarkan 19 pertanyaan.

4) Karyawan yang Bermutu

Karyawan yang kompeten dan jujur, unsur pengendalian yang lain dapat dikurangi sampai batas minimum, dan perusahaan tetap mampu menghasilkan pertanggungjawaban keuangan yang dapat diandalkan. Karyawan yang bermutu diukur berdasarkan 9 pertanyaan.

\section{Analisis Data}

Jenis dan sumber data yaitu data primer dan data sekunder. Data dikumpulkan dengan 3 cara, yaitu interview, observasi, dan kuesioner. Data dianalisa dengan menggunakan analisis deskriptif (khususnya data primer). Selain itu pengujian data menggunakan uji tanda (sign test).

Dalam pengujian sampel kecil, kesimpulan yang diperoleh adalah menerima Ho atau menolak Ho. Taraf nyata sebesar $5 \%$. Jika taraf nyata $\geq$ probabilitas hasil sampel maka Ho diterima dan jika taraf nyata $\leq$ probabilitas hasil sampel maka Ho ditolak. Untuk pengujian sampel besar, yaitu uji tanda yang menggunakan sampel lebih dari atau sama dengan 30 . Uji tanda tersebut menggunakan rumus sebagai berikut :

$$
Z=\frac{2 R-n}{\sqrt{n}}
$$

apabila nilai Z-hitung lebih kecil dari nilai $Z$ pada taraf nyata $(1,67)$ maka Ho diterima dan jika $Z$ hitung lebih besar dari $\mathrm{Z}$ taraf nyata maka Ho di tolak.

\section{HASIL DAN PEMBAHASAN}

Organisasi merupakan suatu bentuk kerjasama dan kerjasama tersebut berlangsung secara tertentu yang meyebabkan adanya bentuk, berdasarkan aturan-aturan dan prinsipprinsip yang tertentu pula. Setiap bentuk 
mesti ada konfigurasinya yang tertentu dan yang disebabkan oleh sesuatu di dalamnya yang disebut dengan struktur. Struktur organisasi yang diterapkan oleh Kantor UED - SP DesaTanah Merah adalah struktur organisasi garis di mana tanggungjawab dan wewenang berada dalam satu garis langsung dari pucuk pimpinan kepada masing-masing petugasnya.

\section{Uji Tanda}

Dalam penelitian ini menggunakan uji tanda ( sign test). Uji Tanda ( Sign Test) yaitu uji yang dilakukan untuk melihat adanya perbedaan dan bukan besarnya perbedaan . Prosedur uji tanda didasarkan pada tanda positif $(+)$ atau negatifve ( - ) dari perbedaan antara pasangan data ordinal.

\section{Struktur Organisasi}

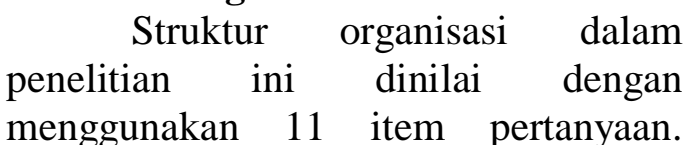
Jumlah tanda positif $(+)$ ada 11 dan jumlah tanda negatif ( - ) ada 0 , sehingga jumlah data yang relevan $n=$ 11. Untuk menentukan Probabilitas menggunakan rumus binomial, dimana $\mathrm{n}=11, \mathrm{r}=0$ sampai 11. Apabila taraf nyata lebih kecil dari probabilitas maka Ho diterima dan jika taraf nyata lebih besar dari probabilitas maka Ho ditolak. Diketahui taraf nyata $=0,05$ dan probabilitas $=0,000488281$. Dengan demikian taraf nyata > Probabilitas, maka Ho ditolak Hi diterima (signifikan), artinya struktur organisasi yang memisahkan tanggung jawab dan wewenang secara tegas tersebut sudah dijalankan dengan baik oleh UED - SP Desa Tanah Merah.

\section{Sistem Otorisasi dan Prosedur Pencatatan}

Sistem otorisasi dan prosedur pencatatan dalam penelitian ini dinilai dengan menggunakan 15 item pertanyaan. Jumlah tanda positif $(+)$ ada 15 dan jumlah tanda negatif ( - ) ada 0 ,sehingga jumlah data yang relevan $\mathrm{n}=$ 15. Untuk menentukan nilai probabilitas dengan menggunakan rumus binomial, dimana $n=15, r=0$ sampai 15 . Apabila taraf nyata lebih kecil dari probabilitas maka Ho diterima dan jika taraf nyata lebih besar dari probabilitas maka Ho ditolak. Diketahui taraf nyata $=0,05$ dan probabilitas $=0,000030518$. Dengan demikian taraf nyata > Probabilitas, maka Ho ditolak Hi diterima ( signifikan ), artinya sistem otorisasi dan prosedur pencatatan sudah dijalankan dengan baik oleh UED - SP Desa Tanah Merah.

\section{Praktik yang Sehat}

Praktik yang sehat dalam penelitian ini dinilai dengan menggunakan 19 item pertanyaan. Jumlah tanda positif $(+)$ ada 16 dan jumlah tanda negative ( - ) ada 3 , sehingga jumlah data yang relevan $\mathrm{n}=$ 19. Untuk menentukan nilai probabilitas dihitung dengan menggunakan rumus binomial, dimana $n=19, r=0$ sampai 19. Apabila taraf nyata lebih kecil dari probabilitas maka Ho diterima dan jika taraf nyata lebih besar dari probabilitas maka Ho ditolak. Diketahui taraf nyata $=0,05$ dan probabilitas $=0,001848221$. Dengan demikian taraf nyata > Probabilitas, maka Ho ditolak Hi diterima ( signifikan ), artinya praktik yang sehat sudah dijalankan dengan baik oleh UED - SP Desa Tanah Merah.

\section{Pengelola yang Bermutu}

Pengelola yang bermutu dalam penelitian ini dinilai dengan menggunakan 9 item pertanyaan. Jumlah tanda positif $(+)$ ada 7 dan jumlah tanda negatif ( - ) ada 2,sehingga jumlah data yang relevan $n=9$. Untuk menentukan Probabilitas dengan menggunakan rumus binomial, dimana $\mathrm{n}=9, \mathrm{r}=0$ sampai 9 . Apabila taraf nyata lebih kecil dari probabilitas maka Ho diterima dan jika taraf nyata lebih besar 
dari probabilitas maka Ho ditolak. Diketahui taraf nyata $=0,05$ dan probabilitas $=0,001953125$. Dengan demikian taraf nyata > Probabilitas, maka Ho ditolak Hi diterima ( signifikan ), artinya pengelola yang bermutu sudah dijalankan dengan baik oleh UED - SP Desa Tanah Merah.

Dari seluruh angket maka diperoleh tanda positif $(+)$ sebanyak 49 ( R ) dan yang negatif ( - ) 5, sehingga jumlah data yang relevan $(\mathrm{n})=54$. Untuk menentukan Probabilitas menggunakan rumus $\mathrm{Z}$, dimana $\mathrm{R}=49$ dan $\mathrm{n}=54$

$$
z \frac{2 R-n}{\sqrt{n}}=\frac{2.49-54}{\sqrt{54}}=\mathbf{5 , 9 8 7 4 1 5 9 3}
$$

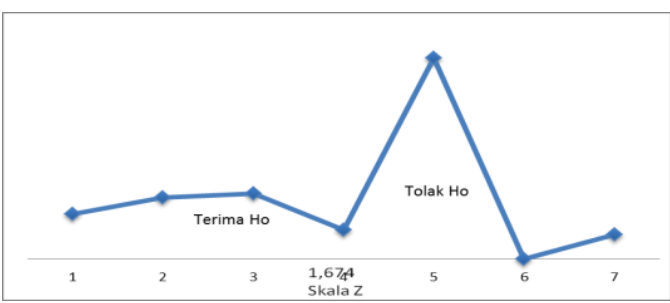

Sumber : Data Olahan

\section{Gambar 1. Kurva Daerah Keputusan Untuk Pengendalian Internal Pemberian Kredit UED-SP Tanah Merah}

Dari hasil perhitungan diperoleh $Z=5,9876$ dimana $Z$ yang diperoleh maka > taraf nyata yang digunakan yaitu sebesar 1,674 yang berarti Ho ditolak dan Hi diterima. Maka kesimpulannya bahwa keseluruhan pengendalian internal pemberian kredit pada Usaha Ekonomi Desa - Simpan Pinjam ( UED-SP ) DesaTanah Merah sudah berjalan dengan efektif. Hal ini sesuai dengan teori Mulyadi (2010:166 ) .
Tabel 1 Hasil Keseluruhan Perhitungan Sign test Pengendalian intern UED-SP DesaTanah Merah

\begin{tabular}{|c|c|c|c|c|}
\hline Dimensi & $\begin{array}{c}\text { Ujji } \\
\text { Sampel }\end{array}$ & Signifikan & Hasil & Keterangan \\
\hline $\begin{array}{l}\text { Struktur } \\
\text { Organisasi }\end{array}$ & Binomial & Signifikan & $\begin{array}{c}1,000000 \\
000> \\
0,95\end{array}$ & $\begin{array}{c}\text { Telah } \\
\text { berjalan } \\
\text { efektif }\end{array}$ \\
\hline $\begin{array}{l}\text { Sistem } \\
\text { Otorisasi } \\
\text { dan } \\
\text { Prosedur } \\
\text { Pencatatan }\end{array}$ & Binomial & Signifikan & $\begin{array}{c}1,000000 \\
000> \\
0,95\end{array}$ & $\begin{array}{c}\text { Telah } \\
\text { berjalan } \\
\text { efektif }\end{array}$ \\
\hline $\begin{array}{l}\text { Praktik } \\
\text { yang } \\
\text { Sehat }\end{array}$ & Binomial & Signifikan & $\begin{array}{c}0,999635 \\
696> \\
0,95\end{array}$ & $\begin{array}{c}\text { Telah } \\
\text { berjalan } \\
\text { efektif }\end{array}$ \\
\hline $\begin{array}{l}\text { Pengelola } \\
\text { (karyawan } \\
\text { ) yang } \\
\text { Bermutu }\end{array}$ & Binomial & Signifikan & $\begin{array}{c}1,070312 \\
500> \\
0,95\end{array}$ & $\begin{array}{c}\text { Telah } \\
\text { berjalan } \\
\text { efektif }\end{array}$ \\
\hline $\begin{array}{l}\text { Pengendal } \\
\text { ian } \\
\text { Internal } \\
\text { Pemberian } \\
\text { Kredit }\end{array}$ & $\begin{array}{c}\text { Uji } \\
\text { Sampel } \\
\text { Besar }\end{array}$ & Signifikan & $\begin{array}{c}5,9876> \\
1,674\end{array}$ & $\begin{array}{c}\text { Telah } \\
\text { berjalan } \\
\text { efektif }\end{array}$ \\
\hline
\end{tabular}

Sumber : Data Olahan 2017

Dari tabel diatas secara keseluruhan hasil probabilitas kumulatif pengendalian internal pemberian kredit adalah 5,9876 > 1,674, maka dapat disimpulkan bahwa pengendalian internal pemberian kredit pada Usaha Ekonomi Desa - Simpan Pinjam ( UED-SP ) DesaTanah Merah telah berjalan dengan efektif.

Tabel 2. hasil perbandingan Teori Unsur Pengendalian Intern

Pemberian Kredit Pada UED - SP

Desa Tanah Merah Kecamatan Siak Hulu Kabupaten Kampar.

\begin{tabular}{|c|c|c|}
\hline No & TEORI & Yang Dijalankan UED - SP \\
\hline & Struktur Organisasi & \\
\hline 1 & $\begin{array}{lr}\text { Suatu fungsi tidak boleh } \\
\text { diberi tanggung jawab } \\
\text { penuh } & \text { untuk } \\
\text { melaksanakan semua } & \text { salap suatu transaksi. }\end{array}$ & $\begin{array}{l}\text { Tidak memberikan tanggung } \\
\text { jawab penuh } \\
\text { melaksanakan semua tahap } \\
\text { suatu transaksi. }\end{array}$ \\
\hline 2 & $\begin{array}{l}\text { Fungsi kas harus terpisah } \\
\text { dari fungsi lainnya Dan } \\
\text { tidak merangkap jabatan } \\
\text { di fungsi lain. }\end{array}$ & $\begin{array}{l}\text { Fungsi kas terpisah dari fungsi } \\
\text { lainnya Dan tidak merangkap } \\
\text { jabatan di fungsi lain. }\end{array}$ \\
\hline 3 & $\begin{array}{lcr}\text { Fungsi } & \text { kredit } & \text { harus } \\
\text { terpisah } & \text { dari } & \text { fungsi } \\
\text { lainnya } & \text { dan } & \text { tidak } \\
\text { merangkap } & \text { jabatan } & \text { di } \\
\text { fungsi lain. } & & \end{array}$ & $\begin{array}{l}\text { Fungsi kredit terpisah dari } \\
\text { fungsi lainnya dan tidak } \\
\text { merangkap jabatan di fungsi } \\
\text { lain. }\end{array}$ \\
\hline 4 & $\begin{array}{l}\text { Fungsi akuntansi harus } \\
\text { terpisah dare fungsi Dan } \\
\text { tidak merangkap jabatan } \\
\text { di fungsi lain. }\end{array}$ & $\begin{array}{l}\text { Fungsi akuntansi terpisah dari } \\
\text { fungsi Dan tidak merangkap } \\
\text { jabatan di fungsi lain. }\end{array}$ \\
\hline 5 & $\begin{array}{l}\text { Harus dipisahkan fungsi - } \\
\text { fungsi operasi dan } \\
\text { penyimpanan dari fungsi } \\
\text { akuntansi }\end{array}$ & $\begin{array}{l}\text { fungsi - fungsi operasi terpisah } \\
\text { dan penyimpanan dari fungsi } \\
\text { akuntansi }\end{array}$ \\
\hline & B. Sistem Otorisasi dan & rosedur Pencatatan \\
\hline
\end{tabular}




\begin{tabular}{|c|c|c|}
\hline 6 & $\begin{array}{l}\text { Setiap transaksi hanya } \\
\text { terjadi atas dasar otorisasi } \\
\text { dari pejabat yang memiliki } \\
\text { wewenang untuk } \\
\text { menyetujui terjadinya } \\
\text { transaksi tersebut }\end{array}$ & $\begin{array}{l}\text { Stiap transaksi hanya terjadi } \\
\text { atas dasar otorisasi dari pejabat } \\
\text { yang memiliki wewenang } \\
\text { untuk menyetujui terjadinya } \\
\text { transaksi tersebut }\end{array}$ \\
\hline 7 & $\begin{array}{l}\text { Costumer yang memiliki } \\
\text { over limit tidak dapat } \\
\text { melakukan pemberian } \\
\text { kredit sama sekali } \\
\text { sebelum tagihan dilunasi. }\end{array}$ & $\begin{array}{l}\text { Costumer yang memiliki over } \\
\text { limit tidak dapat melakukan } \\
\text { pemberian kredit sama sekali } \\
\text { sebelum tagihan dilunasi. }\end{array}$ \\
\hline 8 & $\begin{array}{l}\text { Penerimaan kas diotorisasi } \\
\text { oleh fungsi kas dengan } \\
\text { cara membubuhkan cap } \\
\text { lunas pada pemberian } \\
\text { kredit yang telah selesai. }\end{array}$ & $\begin{array}{l}\text { Penerimaan kas diotorisasi } \\
\text { oleh fungsi kas dengan cara } \\
\text { membubuhkan cap lunas pada } \\
\text { pemberian kredit yang telah } \\
\text { selesai. }\end{array}$ \\
\hline 9 & $\begin{array}{l}\text { Semua data diinput secara } \\
\text { akurat Dan lengkap. }\end{array}$ & $\begin{array}{l}\text { Semua data diinput secara } \\
\text { akurat Dan lengkap. }\end{array}$ \\
\hline 10 & $\begin{array}{l}\text { Pencatatan penerimaan } \\
\text { kas diotorisasi oleh fungsi } \\
\text { akuntansi. }\end{array}$ & $\begin{array}{lcc}\begin{array}{l}\text { Pencatatan } \\
\text { diotorisasi } \\
\text { akuntansi. }\end{array} & \begin{array}{c}\text { penerimaan kas } \\
\text { oleh fungsi }\end{array} \\
\end{array}$ \\
\hline & C. Praktik Yang Sehat & \\
\hline 11 & $\begin{array}{l}\text { Faktur pemberian Kredit } \\
\text { bernomor urut. }\end{array}$ & $\begin{array}{l}\text { Faktur pemberian kredit } \\
\text { bernomor urut }\end{array}$ \\
\hline 12 & Pemeriksaan mendadak & $\begin{array}{ll}\text { Tidak ada pemeriksaan } \\
\text { mendadak }\end{array}$ \\
\hline 13 & $\begin{array}{l}\text { Setiap transaksi tidak } \\
\text { boleh dilaksanakan dari } \\
\text { awal sampai akhir oleh } \\
\text { satu orang atau satu unit } \\
\text { organisasi, tanpa ada } \\
\text { campur tangan dari orang } \\
\text { atau unit organisasi lain. }\end{array}$ & $\begin{array}{l}\text { Setiap transaksi tidak boleh } \\
\text { dilaksanakan dari awal sampai } \\
\text { akhir oleh satu orang atau satu } \\
\text { unit organisasi, tanpa ada } \\
\text { campur tangan dari orang atau } \\
\text { unit organisasi lain. }\end{array}$ \\
\hline 14 & Perputaran jabatan & Tidak ada Perputaran jabatan \\
\hline 15 & $\begin{array}{l}\text { Keharusan pengambilan } \\
\text { cuti bagi karyawan yang } \\
\text { berhak. }\end{array}$ & $\begin{array}{l}\text { Tidak adanya keharusan cuti } \\
\text { bagi karyawan. }\end{array}$ \\
\hline 16 & $\begin{array}{l}\text { Pembentukan unit } \\
\text { organisasi yang bertugas } \\
\text { untuk mengecek } \\
\text { efektifitas unsur }- \text { unsur } \\
\text { sistem pengendalian } \\
\text { internal yang lain. }\end{array}$ & $\begin{array}{l}\text { Tidak ada Pembentukan unit } \\
\text { organisasi yang bertugas untuk } \\
\text { mengecek efektifitas unsur - } \\
\text { unsur sistem pengendalian } \\
\text { internal yang lain. }\end{array}$ \\
\hline & D. Pengelola Yang Berr & utu \\
\hline 17 & 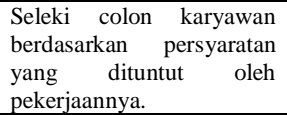 & $\begin{array}{l}\text { Seleki colon karyawan } \\
\text { berdasarkan persyaratan yang } \\
\text { dituntut oleh pekerjaannya. }\end{array}$ \\
\hline 18 & $\begin{array}{l}\text { Pengembangan pendidikan } \\
\text { karyawan selama menjadi } \\
\text { karyawan perusahaan, } \\
\text { sesuai dengan tuntutan } \\
\text { perkembangan } \\
\text { pekerjaannya. }\end{array}$ & $\begin{array}{l}\text { Pengembangan pendidikan } \\
\text { karyawan selama menjadi } \\
\text { karyawan perusahaan, sesuai } \\
\text { dengan tuntutan perkembangan } \\
\text { pekerjaannya. }\end{array}$ \\
\hline 19 & 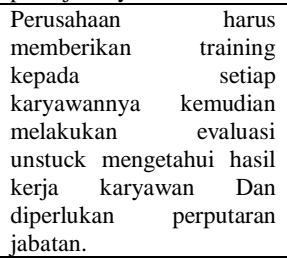 & \begin{tabular}{l}
\multicolumn{3}{l}{ Perusahaan harus memberikan } \\
training kepada setiap \\
karyawannya 4 kemudian \\
melakukan evaluasi untuk \\
mengetahui hasil kerja \\
karyawan Dan diperlukan \\
perputaran jabatan.
\end{tabular} \\
\hline
\end{tabular}

\section{PENUTUP}

\section{Kesimpulan}

Dari hasil angket yang diperoleh, berikut gambaran pengendalian internal pemberian kredit Usaha Ekonomi Desa - Simpan Pinjam ( UED - SP ) Desa tanah Merah sebagai berikut :
1. Pengendalian internal pemberian kredit Usaha Ekonomi Desa Simpan Pinjam ( UED - SP ) Desa Tandah Merah telah memiliki pengendalian tersendiri dalam menjalankan pekerjaan dimana unsur pengendalian nya mencakup struktur organisasi, sistem otorisasi dan prosedur pencatatan, praktik yang sehat serta karyawan yang bermutu. Pengendalian internal pemberian kredit Usaha Ekonomi Desa Simpan Pinjam ( UED - SP ) Desa Tanah Merah, secara keseluruhannya telah berjalan dengan efektif.

2. Struktur Organisasi UED - SP Desa Tanah Merah telah memenuhi pengendalian internal yang baik dan berjalan efektif dimana UED-SP Tanah Merah memiliki struktur organisasi yang jelas dan tidak sering berubah yang dapat menggambarkan garis wewenang serta tanggung jawab karyawannya. Pemisahan fungsi dalam struktur organisasinyapun tidak menyebabkan adanya bagian yang merangkap tugas dan jabatan pada bagian lain serta penetapan sanksi kepada pengelola yang melanggar aturan yang ditetapkan.

3. Sistem Otorisasi dan Prosedur Pencatatan UED-SP Tanah Merah telah berjalan efektif dimana dalam pemberian kredit dan pemberian otorisasi serta dokumen yang digunakan jelas dan tepat. Pengelola menjalankan tanggung jawabnya sesuai wewenang yang diberikan, transaksi yang diproses adalah transaksi yang telah terotorisasi, pemberian otorisasi kredit didelegasikan pada bagian kredit untuk mengontrol prosedur dalam tiap transaksinya, penginputan data dilakukan secara akurat dan tepat.

4. Praktik yang sehat pada UED-SP Tanah Merah telah berjalan efektif dimana penggunaan formulir juga 
lengkap dengan faktur pemberian kredit bernomor urut, pemakaian faktur pemberian kredit dapat dipertanggung jawabkan oleh fungsi kredit. Dimana terdapatnya pemeriksaan atas keabsahan blangko dan juga melakukan penilaian atau evaluasi kredit oleh tim verifikasi serta melakukan kunjungan lapangan oleh tim verifikasi dan juga memberikan umpan balik oleh tim verifikasi. Catatan arsip UED-SP Tanah Merah juga disimpan dan di arsip dengan baik. UED-SP Tanah Merah juga melakukan evaluasi atas kebijakan yang ada didalam UED-SP serta memberikan sanksi untuk setiap pelanggaran yang dilakukan dengan sengaja.

5. Pengelola yang bermutu pada UEDSP Tanah Merah telah berjalan dengan efektif dimana penerimaan pengelola baru tidak sering dilakukan di UED-SP Tanah Merah namun menerima pengelola yang baru melalui test agar memperoleh pengelola yang berkompeten dan memilih pengelola yang memiliki pengetahuan memadai untuk menyelesaikan anggung jawab yang diberikan kepada pengelola tersebut. UED-SP Tanah Merah juga selalu menilai hasil kinerja pengelola agar UED-SP berjalan dengan baik dan sesuai dengan harapan, serta melakukan dan menyelenggarakan pelatihan atau training untuk membantu pengelola meningkatkan kompetensi pekerjakaannya, UED-SP Tanah Merah juga memberikan pengembangan pendidikan kepada pengelola sesuai tuntunan perkembangan pekerjaan.

\section{Saran}

Dari hasil penelitian, ada beberapa saran yang diharapkan dapat dijadikan sebagai masukan dalam menjalankan pengendalian internal pemberian kredit UED-SP Tanah Merah diantaranya :

1. UED-SP Tanah Merah sebaiknya melakukan evaluasi terhadap pengelola atas ketaatan dan prosedur untuk menghindari pelanggaran terhadap kebijakan dan prosedur yang telah ditetapkan dengan cara melakukan pengawasan pelaksanaan serta pemeriksaan dan pencocokan terhadap kelengkapan data, dokumen dan dokumen pendukung dari awal hingga akhir transaksi pada hari terjadinya transaksi.

2. Perlunya pembentukan unit organisasi yang bertugas mengecek efektifitas unsur pengendalian internal pemberian kredit dan melakukan pengecekan saldo kas ditangan fungsi kas serta pemeriksaan mendadak terhadap fungsi - fungsi yang terkait dalam pemberian kredit UED-SP Tanah Merah.

3. Sebaiknya UED-SP Tanah Merah memberikan penghargaan yang pantas bagi pengelola yang berprestasi agar memberikan semangat kinerja dan merasa dihargai dan betah bekerja didalam UED-SP Tanah Merah.

4. Penelitian ini diharapkan dapat menambah pengetahuan mengenai pengendalian internal pemberian kredit dalam UED-SP bagi akademis. Selain itu sebaiknya peneliti selanjutnya juga membandingkan dengan penelitian lainnya yang sejenis untuk dijadikan bahan referensi dalam pengembagan penelitian lebih lanjut.

\section{DAFTAR PUSTAKA}

Hadi, P. H. 2014. Sistem Pengendalian Internal Pemberian Kredit Pada Bank Danamon Cabang Kembang Jepun Surabaya. Sekolah Tinggi 
Ilmu Ekonomi Indonesia (STIESIA). Surabaya

Kasmir. 2004. Analisis Laporan Keuangan. Jakarta Utara. Raja Granada Persada.

Mulyadi. 2008. Sistem Akuntansi. Jakarta. Salemba Empathy..

Mulyadi. 2010. Auditing. Cetakan Ketujuh. Cetakan Jakarta : Salemba Empathy.

Nilawati, N. K. 2016. Sistem Pengendalian Intern Pemberian Kredit Pada Badan Usaha Milik Desa (Bumdes) Desa Pengastulan, Kecamatan Seririt, Kabupaten Buleleng. https://ejournal. undiksha.ac.id/index.php/JJPE/artic le/download/75861Diakses pada tanggal 25 November 2017.

Rahayu dan Suhayati. 2010. Auditing, Konsep Dasar dan Pedoman Pemeriksaan Akuntan Publik. Edisi Pertama. Yogyakarta : Graha Ilmi.

Reeve dkk. 2011. Pengantar AkuntansiAdaptasi Indonesia. Jakarta. Salemba Empathy.

SK Desa : 62/SS-PEMDES/VI/2009, Tanggal 17 Juni 2008, yang di sahkan oleh KAKAN PMD KABUPATEN SIAK.

Singleton 2009. Informasi Technology Auditing and Assurance. Buku 1. Jakarta : Salemba Empathy.

Surat Mendagri Nomor 412/242/2420/SJ Tanggal 26 Oktober 1998.

Widjajanto. 2008. Sistem Informasi Akuntansi. Jakarta. Erlangga 